\title{
Analisis Kemampuan Pemecahan Masalah Matematis Siswa dalam Menyelesaikan Masalah Segitiga Berdasarkan Jenis Kelamin
}

\author{
${\text { Ita } \text { Rosita }^{1} \text {, Andrie Chaerul }}^{2}$, dan Kiki Nia Sania Effendi ${ }^{3}$ \\ ${ }^{1,2,3}$ Program Pendidikan Matematika, Universitas Singaperbangsa
}

\section{Info Artikel Abstract}

Sejarah Artikel:

Diterima 19 Apr 2021

Direvisi 30 Apr 2021

Disetujui 4 Mei 2021

\section{Keywords:}

Triangle, gender,

mathematics, problem-

solving

\section{Paper type:}

Research paper
The purpose of this research is the mathematical problem-solving abilities of male and female students in grade VII Junior High School. The type of research carried out in this research is qualitative with the case study method, using data analysis techniques, namely data analysis model of Miles and Huberman. Activity procedures in data analysis in this study include: data reduction, data presentation, and conclusion drawing. Data collection used test instruments for problem solving abilities on triangular material and unstructured interviews with research subjects. The subjects taken were six students, consisting of three male students and three female students. The data obtained, then analyzed qualitatively. The results of this study indicate that male students are more prominent in the implementation stage only, female students write down the stages of understanding, making, implementing, and checking in order and are more inclined to imitate the previous completion process.

\begin{abstract}
Abstrak
Penelitian ini bertujuan untuk mendeskripsikan dan menganalisis mengenai kemampuan pemecahan masalah matematis pada siswa laki-laki dan siswa perempuan di kelas VII Sekolah Menengah Pertama (SMP). Jenis penelitian yang dilakukan pada penelitian ini adalah kualitatif dengan metode studi kasus, Teknik yang digunakan adalah dengan menggunakan teknik analisis data yaitu analisis data model Miles and Huberman. Prosedur aktivitas dalam analisis data pada penelitian ini meliputi : reduksi data, penyajian data, dan penarikan kesimpulan. Pengumpulan data menggunakan instrumen tes soal berupa kemampuan pemecahan masalah matematis pada materi segitiga dan didukung dengan wawancara secara tidak terstruktur kepada yang dijadikan subjek penelitian. Subjek yang diambil sebanyak enam siswa, yang terdiri dari tiga orang siswa laki-laki dan tiga orang siswa perempuan. Data yang diperoleh kemudian dianalisis secara kualitatif. Hasil penelitian ini menunjukkan bahwa siswa laki-laki lebih menonjol dalam tahap pelaksanaan saja, siswa perempuan menuliskan tahapan memahami, membuat, melaksanakan, dan memeriksa secara terurut dan lebih condong kepada proses meniru penyelesaian sebelumnya.
\end{abstract}

(C) 2021 Universitas Muria Kudus

\footnotetext{
Alamat korespondensi:

Program Studi Pendidikan Matematika

Fakultas Keguruan dan Ilmu Pendidikan Universitas Muria Kudus

Kampus UMK Gondangmanis, Bae Kudus Gd. L. 1t I PO. BOX 53 Kudus

Tlp (0291) 438229 ex.147 Fax. (0291) 437198

E-mail: 1610631050076@student.unsika.ac.id
}

p-ISSN 2615-4196 
Ita Rosita, Andrie Chaerul, dan Kiki Nia Sania Effendi

Anargya: Jurnal Pendidikan Matematika, Vol. 4 No.1, April 2021

https://dx.doi.org/10.24176/anargya.v4i1.6139

\section{PENDAHULUAN}

Kedudukan matematika yang memiliki peranan begitu penting, berbanding terbalik dengan fakta yang terjadi. Matematika menjadi momok yang membuat siswa beranggapan bahwa mata pelajaran tersebut membosankan. $\mathrm{Hal}$ tersebut dipacu oleh beberapa faktor yang menjadi penyebab. Sebagaimana diperjelas (Ulya, 2015) mengutarakan bahwa rendahnya kemampuan matematika menyebabkan munculnya sikap ketidaksenangan siswa terhadap pelajaran matematika.

Dalam mata pelajaran matematika, siswa akan selalu dihadapkan pada sebuah permasalahan. Siswa dituntut untuk memiliki kemampuan dalam pemecahan masalah. Menurut (Fazzilah dan Effendy, 2019) pemecahan masalah adalah upaya yang dilakukan seseorang untuk menemukan solusi dari masalah yang sedang dihadapinya. Pemecahan masalah ini salah satu hal yang paling krusial. Sebagaimana Branca (dalam Sumarmo, Rohaeti, dan Herdiana, 2017) mengemukakan bahwa kemampuan pemecahan masalah matematis meliputi metode, prosedur, dan strategi yang merupakan proses inti dan utama dalam kurikulum matematika atau merupakan tujuan umum pembelajaran matematika, bahkan sebagai jantungnya matematika.

Salah satu masalah matematika yang mengaitkan dengan kehidupan sehari-hari yaitu masih rendahnya tingkat pemecahan masalah dalam soal kontekstual. Masalah kontekstual ini penting untuk dipelajari siswa, agar materi matematika yang dipelajari dapat mudah dimengerti karena tergambar secara nyata dalam aplikasi kehidupan sehari-hari. Apalagi kemampuan pemecahan masalah ini merupakan kemampuan yang melibatkan analisis tingkat tinggi. Namun, masalah kontekstual tidak serta merta menjadikan matematika pasti lebih mudah sebab penerapannya berdasarkan potensi siswa dalam kegiatan belajar matematika (Jayanti, Irawan, dan Irawati, 2018)

Kemampuan memecahkan masalah perlu untuk terus diasah bagi siswa, baik laki-laki ataupun perempuan. Ditinjau dari kemampuan laki-laki dan perempuan secara umum, keduanya jelas merupakan dua obyek yang berbeda. Sebagaimana (Amin, 2018) mengutarakan mengenai perbedaan struktur otak dan prilaku belajar pria dan perempuan, eksplansi dalam sudut pandang neurosains dan filsafat bahwa laki-laki pada umumnya lebih mudah dalam mempelajari suatu hal yang hands-on (aksi) sedangkan perempuan lebih kepada cara dan gaya belajar berbasis komunikasi.
Siswa dalam menyelesaikan persoalan matematika menggunakan cara yang berbedabeda, karena kemampuan matematika yang dimiliki pun berbeda. Pendapat yang dikemukakan oleh Eleanor Maccoby dan Carol Jacklin (dalam Santrock, 2007) menyampaikan bahwa laki-laki biasanya memiliki kemampuan pada bidang matematika dan visuospasial yang lebih baik, sedangkan perempuan lebih baik dari aspek kemampuan verbalnya. Selain itu hasil penelitian (Wardani 2016) mengenai kemampuan pemecahan masalah berdasarkan perbedaan jenis kelamin mengutarakan bahwa profil kemampuan pemecahan masalah ditinjau dari jenis kelamin bahwa siswa laki-laki tidak mampu melaksanakan rencana dan memeriksa kembali sedangkan siswa perempuan mampu melaksanakan rencana dan memeriksa kembali walaupun belum lengkap.

Berdasarkan uraian diatas, peneliti tertarik akan kemampuan pemecahan masalah matematis di SMP Negeri 2 Karawang yang menunjukkan bahwa dari hasil nilai rapornya perbedaan signifikan terjadi pada siswa laki-laki dan siswa perempuan. Sehingga, peneliti akan menganalisa mengenai kemampuan pemecahan masalah matematis siswa berdasarkan jenis kelamin pada laki-laki dan perempuan.

\section{METODE PENELITIAN}

Peneliti menggunakan pendekatan kualitatif dalam proses penelitiannya dan metode penelitian yang peneliti gunakan adalah studi kasus. Penelitian ini dilaksanakan di kelas VII-G pada semester genap tahun ajaran 2019/2020 di SMP Negeri 2 Karawang Barat. Pengumpulan data dilakukan melalui teknik tes dengan memberikan instrumen tes soal kemampuan pemecahan masalah matematis serta didukung dengan melakukan proses wawancara. Peneliti mengambil sasaran, pada salah satu kelas dari total bejumlah 10 kelas, yaitu pada kelas VII-G.

Jumlah responden kelas VII-G yang dijadikan subjek penelitian adalah sebanyak 30 siswa. Dari seluruh siswa kelas VII-G yang berjumlah tiga puluh, maka peneliti kemudian mengambil 6 siswa untuk dijadikan subjek mengenai kemampuan pemecahan masalah matematis berdasarkan skor yang diperoleh siswa dalam menyelesaikan tes kemampuan pemecahan. Enam siswa yang diambil terdiri dari 3 orang siswa laki-laki dan 3 orang siswa perempuan, masing-masing dalam peringkat perolehan skor berkategori tinggi, sedang, dan rendah.

Tabel 1. Pengkategorian Tinggi, Sedang, Rendah

\begin{tabular}{ll}
\hline Kategori & Kriteria \\
\hline Tinggi & Mean $+1 \mathrm{SD}>\mathrm{X}$ \\
Sedang & Mean $-1 \mathrm{SD}<\mathrm{X}<$ Mean $+1 \mathrm{SD}$ \\
\hline
\end{tabular}


Ita Rosita, Andrie Chaerul, dan Kiki Nia Sania Effendi

Anargya: Jurnal Pendidikan Matematika, Vol. 4 No.1, April 2021

https://dx.doi.org/10.24176/anargya.v4i1.6139

Rendah $\quad \mathrm{X}<$ Mean -1 SD

Pengkategorian ini berdasarkan dari

pengkategorian tinggi, sedang, dan rendah. (Arikunto, 2018). Proses analisis data yang dilakukan adalah teknik analisis data yang digunakan dengan analisis data model Miles and Huberman.

\section{HASIL DAN PEMBAHASAN}

Penelitian ini bertujuan untuk mengetahui kemampuan pemecahan masalah matematis dalam menyelesaikan materi segitiga berdasarkan dari jenis kelamin siswa baik itu laki-laki atau Tabel 2. Kemampuan Pemecahan Masalah

\begin{tabular}{lllll}
\hline Subjek & \multicolumn{2}{l}{ Indikator } \\
\hline & MI & M2 & M3 & M4 \\
\hline MRR (L) & $\sqrt{ }$ & $\sqrt{ }$ & $\sqrt{ }$ & $\sqrt{ }$ \\
MMF (L) & - & $\sqrt{ }$ & $\sqrt{ }$ & - \\
RM (L) & - & - & $\sqrt{ }$ & - \\
SAF (P) & $\sqrt{ }$ & $\sqrt{ }$ & $\sqrt{ }$ & $\sqrt{ }$ \\
SK (P) & $\sqrt{ }$ & $\sqrt{ }$ & - & $\sqrt{ }$ \\
AZ (P) & $\sqrt{ }$ & - & $\sqrt{ }$ & - \\
\hline
\end{tabular}

Catatan:

M1 = Memahami masalah

M2 = Memahami Rencana

M3 = Melaksanakan

M4 = Memeriksa

\section{Kemampuan Pemecahan Masalah Matematis Siswa Laki-laki}

Berdasarkan hasil wawancara dengan siswa peneliti memperoleh beberapa permasalahan mengenai kemampuan pemecahan masalah matematis. Melalui kombinasi antara hasil tes dan wawancara, diperoleh bahwa siswa laki-laki dengan kemampuan tinggi sudah dapat memahami pada semua nomor soal. Kemampuan memahami ini dilihat dari kemampuan siswa dalam menentukan apa yang diketahui dan ditanyakan pada soal. Pada soal nomor satu siswa menuliskan panjang sisi segitiga, serta menuliskan panjang minimal pita yang dperlukan pada bagian ditanya. Soal nomor dua siswa menuliskan besar-besar sudut sesuai yang tertera dalam soal. Siswa menuliskan besar sudut a dan b pada bagian yang ditanyakan. Soal nomor tiga siswa menuliskan jarak rumah Andi ke taman dan sisi-sisi taman, serta menulis lebih jauh mana jarak rumah ke taman atau mengelilingi dua putaran taman pada bagian ditanya. Kemampuan merencanakan penyelesaian siswa laki-laki dengan kemampuan tinggi sudah baik. Siswa membuat perencanaan dengan memisalkan apa yang diketahui dari soal dalam bentuk matematika yaitu panjang sisi $\mathrm{AB}$ dan $\mathrm{AC}$, dan menuliskan rumus yang digunakan untuk perempuan. Berdasarkan hasil tes kemampuan pemecahan masalah, perlu dianalisis penyelesaian siswa berasarkan langkah Polya. Kemudian, guna mendapatkan hasil yang berkesinambungan dan membandingkan perolehan siswa dari soal tes, dilakukanlah wawancara terhadap subjek yang telah ditentukan sebelumnya dalam kategori tinggi, sedang, dan rendah. Soal tes berjumlah 4 butir soal.

Berikut adalah deskripsi kemampuan pemecahan masalah siswa dalam menyelesaikan soal cerita aljabar ditinjau dari perbedaan jenis kelamin.

menghitung panjang sisi dengan perbandingan dan keliling segitiga. Kemampuan melaksanakan rencana dilakukan dengan perhitungan yang dilakukan oleh siswa dan mengoperasikan sesuai dengan perkalian silang. Kemampuan melihat kembali jawaban dilihat dari jawaban siswa saat dilakukan penyelesaian yang menyatakan siswa tersebut sudah melakukan pengecekan jawaban serta menuliskan kesimpulan. Siswa laki-laki dengan kemampuan sedang tidak dapat memahami pada semua nomor soal. Siswa hanya menuliskan langsung aplikasi pelaksanaan rumus, tidak menuliskan hal yang diketahui dan ditanya.

Kemampuan merencanakan penyelesaian hanya pada nomor tiga dan empat siswa menuliskan rumus keliling segitiga dengan sisi+sisi+sisi sedangkan pada soal nomor empat menuliskan rumus luas segitiga. Tahap melaksanakan rencana siswa sudah mampu mengoperasikan rumus pada segitiga. Soal nomor satu siswa salah, karena aplikasi rumus yang digunakanpun tidak tepat. Kemampuan melihat kembali jawaban, siswa tidak melakukan pengecekan pada pengerjaanya. Siswa laki-laki dengan kemampuan rendah dapat memahami soal nomor satu dan dua, dimana siswa tersebut dapat menuliskan hal yang diketahui dan ditanyakan dari soal dengan benar. Kemampuan merencanakan pada siswa benar pada soal nomor empat, sedangkan nomor satu, dua dan tiga salah. Siswa salah karena tidak menuliskan permisalan atau menuliskan rumus yang digunakan pada nomor satu dan dua, serta tidak tepat menghitung pada soal nomor tiga. Kemampuan melaksanakan penyelesaian, siswa benar pada soal nomor empat yaitu mengoperasikan rumus dari segitiga, namun salah dalam hasil akhir karena perhitungan yang kurang tepat, serta dalam kemampuan memeriksa kembali tidak tampak tahap memeriksa kembali.

Berikut ini contoh hasil pekerjaan siswa laki-laki dalam menyelesaikan materi segitiga: 
Ita Rosita, Andrie Chaerul, dan Kiki Nia Sania Effendi

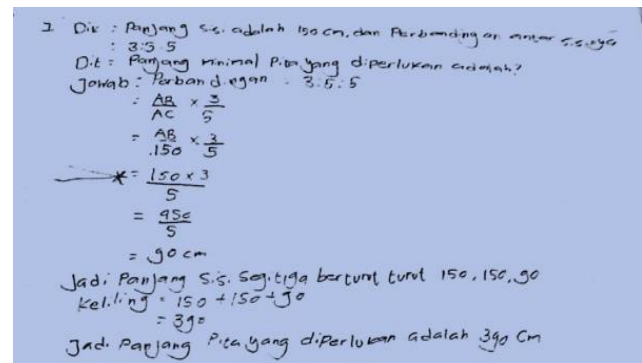

Gambar 1. Contoh Hasil Pengerjaan Siswa Laki-Laki

Berdasarkan hasil pemaparan, dapat dilihat bahwa kemampuan pemecahan masalah siswa laki-laki dalam memahami, merencanakan, melaksanakan dan melihat kembali, masih terdapat kesalahan. Siswa laki-laki pada kategori tinggi dalam memahami masalah selalu terdapat kekurangan informasi ataupun sedikit salah yaitu, dalam aspek penulisan yang dilakukan oleh subjek. Sebagaimana sejalan dengan penelitian (Salmina \& Nisa, 2018) sebagian besar siswa laki- laki cenderung kurang cermat, kurang teliti, serta kurang percaya diri dalam menyelesaikan soal tes. Sedangkan dalam membuat sebuah perencanaan bisa dikatakan tidak konsisten. Sebagaimana hasil penelitian dari (Firmanti, 2017) bahwasanya siswa laki-laki menggunakan penyelesaian yang lebih fleksibel dibandingkan perempuan. Dari hasil penelitian tersebut, menunjukkan bahwa laki-laki memiliki sisi flesibilitas yang artinya berubah- ubah dalam menggunakan penyelesaian cara. Subjek cenderung menuliskan secara singkat tahapan pelaksanaan dalam menyelesaikan soal. Pada tahap memeriksa kembali tampak menuliskan kesimpulan yang diperoleh dari penyelesaian yang telah dikerjakannya. Meskipun, pada nomor dua tidak disertai tahapan dalam memeriksa kembali. Terlebih jika soal tersebut soal yang mudah. Biasanya subjek enggan mengoreksi kembali karena sudah yakin. Hal ini sejalan dengan hasil penelitian yang telah dilakukan oleh (Sari \& Aripin, 2018) yang menyatakan bahwa siswa terkadang terlalu terburu-buru dalam menyelesaikan persoalan yang diberikan.

Berbeda pada siswa laki-laki dengan kategori sedang, dimana subjek sebenarnya sedikit memahami apa yang menjadi tujuan dari soal. Tetapi, subjek tidak menuliskan dan melibatkan informasi dengan menyertakan apa yang diketahui dan apa yang ditanyakan dalam soal. Sebagaimana hasil penelitian (Ishak \& Irmayanti, 2018) menyebutkan bahwa dalam kategori sedang, pada tahap pemahaman masalah, siswa laki-laki tidak menuliskan atau dengan kata lain tidak memahami masalah dengan bahasanya sendiri. Siswa tampak selalu membuat sketsa gambar segitiga baik itu bangun datar yang telah ditulis dan tertuang dalam soal dan menuliskannya kembali, maupun sketsa gambar segitiga dengan kesadaran membuat sendiri. Sejalan dengan hasil penelitian (Susilowati, 2016) bahwa ketika mengkomunikasikan atau dalam membuat sebuah permasalahan, siswa laki-laki cenderung melalui sketsa gambar. Subjek melaksanakan rencana selalu menyelesaikan dengan cara yang tidak berteletele, namun mampu berpikir logis. Sejalan dengan penelitian (Purwanto, Sukestiyarno, \& Junaedi, 2019) bahwasanya siswa laki-laki dalam melaksanakan rencananya cenderung membuat hal-hal yang sederhana dan simpel, ia tidak tampak menuliskan kembali atau mengecek kembali pengerjaannya.

Siswa laki-laki kategori rendah tidak mengetahui masalah. Disamping itu, tidak selalu membuat sebuah perencanaan dalam mengerjakan penyelesaian soal. Ia juga tidak menyertakan dan menuliskan rumus apa yang digunakan dalam penyelesaiannya, tidak menuliskan besaran panjang seperti satuan meter pada soal nomor tiga mengenai keliling taman. Hal tersebut sejalan dengan penelitian (Novitasari \& Wilujeng, 2018) bahwa subjek yang berkemampuan rendah, hanya dapat menyebutkan rumus tersebut, tetapi tidak mengetahui cara penggunaannya. Subjek melaksanakan rencana tetapi tidak memahami inti dari soal tersebut. Hasil jawaban subjek menggunakan cara-cara sendiri tanpa mendasar, sehingga terkesan asal-asalan dalam menjawab. Sebagaimana hasil penelitian (Dilla, Hidayat, \& Rohaeti, 2018) siswa dengan resiliensi (kemampuan/kapasitas) matematika yang kurang, cenderung mengerjakan apa adanya, bahkan tidak selesai sampai proses hasil akhir penyelesaian soal karena adanya perasaan takut salah dan kurangnya ketertarikan menjawab soal baik lakilaki maupun perempuan. Subjek lebih sering tidak memeriksa kembali pengerjaannya. Sebagaimana hasil (Aras, Arifin, \& Zahrawati, 2017) pada tahap memeriksa kembali, subjek laki-laki tidak mengecek kembali jawaban yang telah diperolehnya dan cepat puas dengan apa yang mereka dapatkan meskipun dalam proses penyelesaian terkadang terdapat kesalahan yang tidak disadari.

Berdasarkan penjelasan diatas kemampuan pemecahan masalah matematis pada siswa lakilaki kategori tinggi dapat memahami masalah, membuat rencana, memeriksa kembali dengan tidak konsisten, serta melaksanakan rencana secara singkat. Siswa laki-laki kategori sedang tidak menuliskan komponen yang diketahui dan 
Ita Rosita, Andrie Chaerul, dan Kiki Nia Sania Effendi

Anargya: Jurnal Pendidikan Matematika, Vol. 4 No.1, April 2021

https://dx.doi.org/10.24176/anargya.v4i1.6139

ditanyakan, membuat perencanaan dengan sketsa bangun datar segitiga, melaksanakan rencana secara singkat, dan hasil pengerjaannya selalu tidak dikoreksi kembali. Sedangkan, siswa lakilaki dengan kategori rendah tidak memahami masalah, tidak menyertakan rumus dan menyusun perencanaan, melaksanakan perhitungan, namun bersinggungan dengan maksud tujuan soal yang diharapkan, serta cenderung tidak memeriksa kembali hasil pengerjaannya. Sehingga siswa laki- laki hanya menonjol di tahap melaksanakan rencananya, dibanding tahap-tahap lain. Sebagaimana Sejalan dengan penelitian (Aminah \& Kurniawati, 2018) berdasarkan langkahlangkah dalam menyelesaikan soal cerita, kesulitan yang paling banyak dialami oleh siswa laki-laki adalah kesulitan pada langkah pertama dan kedua, dimana siswa laki-laki tidak mengungkapkan informasi yang lengkap terutama apa yang ditanyakan oleh soal.

\section{Kemampuan Pemecahan Masalah Matematis Siswa Perempuan}

Berdasarkan hasil wawancara dengan siswa, peneliti kemampuan pemecahan masalah matematis siswa. melalui kombinasi antara hasil tes dan wawancara, diperoleh bahwa siswa perempuan sama dengan siswa laki-laki kategori tinggi, yaitu menuliskan komponen apa saja yang diketahui dan ditanyakan. Kemampuan merencanakan penyelesaian siswa perempuan dengan kemampuan tinggi sudah baik. Siswa membuat perencanaan dengan selalu mensketsakan segitiga dari awal sampai akhir soal. Dilihat dari kemampuan melaksanakan rencanapun dilakukan siswa perempuan dengan tepat dan hasilnya benar. Pengaplikasian rumus dengan pengerjaanpun sesuai dan tepat. Kemampuan melihat kembali jawaban dilihat dari jawaban siswa yang selalu menuliskan kesimpulan dari soal nomor satu sampai empat.

Siswa perempuan dengan kemampuan sedang dapat memahami pada soal. Hanya saja, pada nomor 3 , siswa tidak menuliskan komponen yang diketahui dan ditanyakan. siswa hanya menuliskan hal itu, jika dirasa pertanyaan tersebut mampu ia jawab, tegasnya. Tahap membuat rencanapun, masih ia tunjukkan dengan menuliskan rumus dengan benar pada soal, dengan kata lain, sudah mampu mengoperasikan rumus pada segitiga. Pada tahap melaksanakan, karena pada awalnya selalu ada aktivitas dalam membuat rencana dengan tepat, maka penyelesaian soal yang dihitungpun mampu dilakukan siswa perempuan dengan baik. Namun, ketika ditanya melalui wawancara. Ia jarang menyelesaikan jawaban jika soalnya memang benar-benar tidak ia pahami, seperti halnya pada kasus nomor 3 yang hanya dijawab berbentuk argumen tidak ada langkah penyelesaian. Soalsoal dari nomor 1 dan 4 selalu menuliskan kesimpulan dan memeriksa kembali jawabannya dengan aktivitas tersebut.

Siswa perempuan dengan kemampuan rendah dapat memahami soal hanya nomor dua, tiga, dan empat karena dapat menuliskan hal yang diketahui dan ditanyakan dari soal dengan benar. Tahap merencanakan pada siswa tidak dilakukan, karena rumus yang dibuatpun terdapat kekeliruan bukan terkait rumus segitiga. Sama halnya dengan siswa laki-laki yang karena tidak menuliskan permisalan atau menuliskan rumus yang digunakan pada nomor satu dan dua, serta tidak tepat dalam perhitungan. Kemampuan melaksanakan penyelesaian, siswa benar pada soal nomor tiga dan empat yaitu mencari keliling dan luas dari segitiga, namun salah dalam hasil akhir karena perhitungan yang kurang tepat, serta dalam kemampuan memeriksa kembali tidak tampak tahap memeriksa kembali. Berikut ini contoh hasil pekerjaan siswa perempuan dalam menyelesaikan materi segitiga:

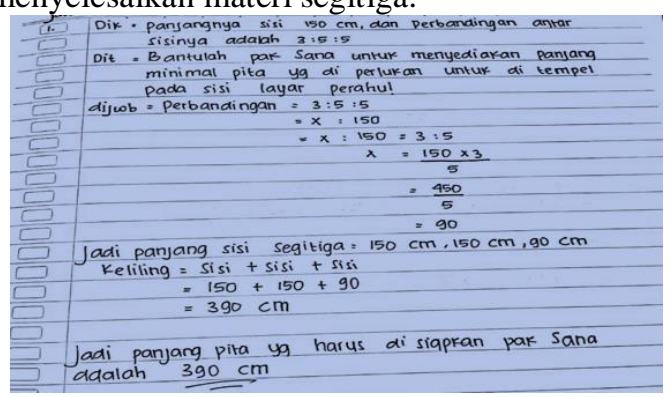

Gambar 2. Contoh Hasil Pengerjaan Siswa Perempuan

Siswa perempuan dalam kategori tinggi selalu menuliskan apa yang diketahui dan ditanyakan dengan sangat terurut dan rapi dalam hal penulisan, serta sesuai dengan yang terdapat dalam informasi soal. subjek membuat perencanaan disamping menuliskan rumus juga selalu membuat terlebih dahulu sketsa gambar segitiga yang dimaksudkan untuk memberi kemudahan dan gambaran saat dirinya mengerjakan hasil jawaban. Sebagaimana hasil penelitian (Febryana, 2018) bahwa siswa perempuan bisa dikatakan lebih kreatif dari siswa laki-laki. siswa perempuan kurang bermain dalam berpikir logisnya dibanding hasil laki-laki. Pada tahap melaksanakan, pasalnya, meskipun pengerjaan soal yang dilakukan nyaris bernilai benar, namun dari hasil wawancara subjek tidak terlalu menguasai jawaban yang telah diselesaikan karena pengerjaannya hanya mengandalkan tipe soal yang sejenis dengan soal- 
Ita Rosita, Andrie Chaerul, dan Kiki Nia Sania Effendi

Anargya: Jurnal Pendidikan Matematika, Vol. 4 No.1, April 2021

https://dx.doi.org/10.24176/anargya.v4i1.6139

soal yang pernah diberikan guru ataupun soal di sumber lain. Sebagaimana hasil penelitian (Susilowati, 2016) dalam menyelesaikan masalah yang diberikan, siswa perempuan melaksanakan rencana sesuai dengan strategi yang telah direncanakan urut mulai dari hal yang diketahui sampai dengan hasil akhir yang ditemukan. Dari total empat butir soal, subjek selalu menuliskan kembali hasil akhir dari perhitungan yang telah diperolehnya walaupun hasil yang diharapkan belumlah sesuai. Sejalan dengan penelitian (Maswar, 2019) perempuan berkemampuan tinggi dalam langkah-langkah pemecahan tidak ada suatu langkah/tahapan yang terabaikan serta membandingkan hasil akhir atau kesimpulan yang satu dengan lainnya disesuaikan dengan apa yang diketahui dan yang ditanyakan pada soal.

Sedangkan dalam kategori sedang, siswa perempuan masih tetap mengerjakan prosedur soal dengan menyertakan hal apa saja yang diketahui dan ditanyakan dalam soal secara benar dan juga tepat. Selain itu, terdapat aktivitas yang mengarahkan kepada penyelesaian caranya dengan membuat perencanaan, seperti menuliskan rumus terlebih dahulu sebelum menjawab soal. Namun, tahap membuat rencana tersebut tidak secara keseluruhan dilakukan oleh siswa perempuan pada kategori rendah. Pasalnya, sama seperti di tahapan memahami masalah, siswa cenderung menyerah dan tidak mencoba terlebih dahulu menggunakan tahapan secara terurutnya pada soal-soal yang menurutnya sulit. Sehingga, tahapan itupun dilewati olehnya tanpa dituliskan terlebih dahulu. Sebagaimana hasil penelitian (Tias \& Wutsqa, 2015) Dalam memecahkan masalah matematika siswa kurang teliti, tergesa-gesa dalam mengerjakan soal, lupa, kurang waktu untuk mengerjakan soal, cepat menyerah, terkecoh, dan cemas. Kemudian pada beberapa soal, siswa dalam kategori sedang bahkan tidak menuliskan pelaksanaan penyelesaian dari soal. Subjek hanya menjawabnya langsung secara pendapat pribadi tanpa dihitung tahap demi tahap karena menganggap pertanyaannya menurut logika. Dalam hal ini, subjek tidak dapat menuliskan hal yang dimaksudkan dalam soal. Namun, ketika dalam wawancara, subjek sebenarnya cukup mengetahui alur yang seharusnya dalam pelaksanaan. Sebagaimana (Ishak \& Irmayanti, 2018) perempuan kurang percaya diri dan berterus terang ketika menyampaikan pendapat padahal dugaan yang disampaikan sudah tepat). Siswa perempuan dengan kategori sedang selalu menunjukkan aktivitas yang mengarah kepada tahap memeriksa kembali pengerjaanya. Dari total empat butir soal, hanya di nomor tiga subjek tidak melakukan tahapan mengecek kembali seperti meyimpulkan di nomor-nomor yang lain.

Disamping itu, siswa perempuan dalam kategori rendah secara garis besar masih menuliskan komponen apa saja yang diketahui dan ditanyakan. Namun pada aplikasinya, siswa perempuan dalam kategori rendah meskipun menuliskan apa yang diketahui dan ditanyakan, tetapi tidak secara rinci dan jawaban cenderung salah dan keliru dari apa yang dimaksudkan dalam soal. Dari ketiga kategori tersebut, secara garis besar subjek selalu menuliskan apa yang diketahui dan ditanyakan meskipun dalam rincian penjabarannya terdapat kekurangan,

dibandingkan tahap memahami pada siswa lakilaki secara umum dari setiap kategori. Perempuan lebih cepat menangkap isi dari permasalahan soal, dan menuangkannya dalam komponen diketahui dan ditanyakan. Sehingga pada langkah memahami masalah, sebagaimana hasil penelitian (Aini, 2017) berpendapat bahwa laki-laki membutuhkan waktu yang lebih lama daripada perempuan dalam memahami masalah. Pengerjaannya dalam membuat rencana terlihat dari cara menjawabnya dengan memvisualkan bangun datar segitiga terlebih dahulu. Tetapi sketsa tersebut tidak memberikan informasi apapun, karena layaknya membuat lukisan perahu berbentuk segitga. Ia tidak menuliskan rumus yang berkaitan dengan tujuan soal yang diharapkan. Sebagaimana hasil penelitian (Afifah, Susanto, Sugiarti, Sunardi, \& Monalisa, 2019) Siswa perempuan yang berada pada level analisis mempunyai keterampilan visual, keterampilan verbal, keterampilan logika, dan keterampilan terapan. Disamping itu, siswa perempuan dalam kategori rendah dalam tahapnya melaksanakan rencana, tidak mengetahui rumus yag bersangkutan dengan pertanyaan soal. Subjek bahkan menuliskan rencana penyelesaian dengan rumus bidang datar segitiga tetapi dalam wujudnya bukan merujuk kepada bidang datar segitiga yaitu menulis $4 \mathrm{x}$ sisi. Kesalahan rumus yang dilakukan oleh subjek bernilai fatal karena berimbas pada hasil akhir penyelesaian. Sebagaimana sejalan dengan penelitian (Kurniadi \& Purwaningrum, 2018) bahwa siswa salah dalam menentukan rumus dan salah dalam menentukan operasi matematika yang digunakan. Pada pengerjaannya, subjek tidak tampak aktivitas memeriksa kembali jawabannya. Hasil akhir yang diperoleh hanya berhenti sampai disitu, tanpa ada jawaban yang mengarah kepada tahap mengecek kembali pengerjaannya. Hasil penelitian (Pardjijanti, 2019) siswa berkemampuan tingkat rendah, kebanyakan dari mereka masih kurang dalam memahami soal dan 
Ita Rosita, Andrie Chaerul, dan Kiki Nia Sania Effendi

Anargya: Jurnal Pendidikan Matematika, Vol. 4 No.1, April 2021

https://dx.doi.org/10.24176/anargya.v4i1.6139

belum mampu untuk memenuhi indikator keempat.

Berdasarkan penjelasan diatas kemampuan pemecahan masalah matematis pada siswa perempuan berkategori tinggi memahami permasalahan dan menuliskan informasi soal secara terurut dan terstruktur, membuat sketsa segitiga, menuliskan perencanaan rumus, melaksanakan prosedur meskipun terdapat kekeliruan, serta selalu mengoreksi dan menyimpulkan hasil akhir. Sejalan dengan hasil penelitian (Nursyahidah, Rubowo, \& Saputro, 2018) yang menyatakan siswa dengan kemampuan tinggi dapat memahami masalah, membuat rencana penyelesaian, melaksanakan rencana dan melihat kembali hasil hasil yang diperoleh. Pada kategori sedang, siswa menuliskan komponen apa yang diketahui dan ditanyakan, membuat rencana dan melaksanakan penyelesaian dengan menuliskan rumus, serta memeriksa dengan menyimpulkan pengerjaan jawaban soalnya. Siswa perempuan kategori rendah menuliskan informasi soal tetapi salah dan keliru dalam menuliskan data yang diperolehnya, tidak membuat perencanaan, melaksanakan prosedur dengan penggunaan rumus yang salah, dan tidak mengecek kembali jawaban akhirnya. Sebagaimana (Lestari, 2019) kemampuan menyelesaikan soal tidak dapat dilakukan oleh siswa perempuan dengan kemampuan sedang dan rendah.

\section{SIMPULAN}

Berdasarkan pemaparan diatas diperoleh bahwa kemampuan pemecahan masalah matematis siswa laki-laki dan perempuan kategori memenuhi empat indikator, pada kategori sedang siswa laki-laki memenuhi tahap membuat dan melaksanakan, siswa perempuan memahami, membuat, dan memeriksa kembali. Sedangkan pada kategori rendah siswa laki-laki hanya memenuhi indikator melaksanakan dan sedikit keliru, siswa perempuan memenuhi tahap memahami masalah dan melaksanakan. Sehingga siswa laki-laki lebih menonjol dalam tahap pelaksanaan saja, Siswa perempuan menuliskan tahapan memahami, membuat, melaksanakan, dan memeriksa secara terurut dan lebih condong kepada proses meniru penyelesaian sebelumnya, maka dapat dikatakan bahwa kemampuan pemecahan siswa perempuan lebih unggul dari siswa laki-laki.

\section{DAFTAR PUSTAKA}

Aini, K. N. 2017. Proses Berpikir Mahasiswa Laki-laki dan Perempuan dengan Gaya
Kognitif Field Independent dalam Memecahkan Masalah. Inspiramatika : Jurnal Inovasi Pendidikan dan Pembelajaran Matematika. 3 (1), 16-23.

Amin, M. S. 2018. Perbedaan Struktur Otak dan Perilaku Belajar Antara Pria. Jurnal Filsafat Indonesia, 1 (1), 38-43.

Aminah, \& Kurniawati, K. A. 2018. Analisis Kesulitan Siswa dalam Menyelesaikan Soal Cerita Matematika Topik Pecahan Ditinjau Dari Gende. JTAM : Jurnal Teori dan Aplikasi Matematika, 2 (2), 118-122.

Aras, A., Arifin, S., \& Zahrawati, F. 2017. Pemecahan Masalah Matematika Siswa Al-Fityan School Gowa. Al-Maiyyah: Media Transformasi Gender dalam Paradigma Sosial Keagamaan. 1 (1), 617621.

Arikunto, S. 2018. Dasar-dasar Evaluasi Pendidikan. Jakarta: Bumi Aksara.

Dilla, S. C., Hidayat, W., \& Rohaeti, E. E. 2018. Faktor Gender dan Resiliensi dalam Pencapaian Kemampuan Berpikir Kreatif Matematis Siswa SMA. Journal of Medives. 2 (1), 129-136.

Fazzilah, E., \& Effendi, K. N. 2019. Strategi Pemecahan Masalah Siswa Kelas VIII Pada Soal PISA Like. Prosiding Seminar Nasional Matematika dan Pendidikan Matematika, (hal. 883-891).

Febryana, D. 2018. Profil Kreativitas Siswa dalam Menyelesaikan Soal Segitiga dan. Suska. Journal of Mathematics Education, 4 (1), 50-58.

Firmanti, P. 2017. Penalaran Siswa Laki-laki dan Perempuan dalam Proses Pembelajaran Matematika. Humanisma: Journal of Gender Studies. 1 (2), 73-85.

Hendriana, H., Rohaeti, E. E., \& Sumarmo, U. 2017. Hard Skill dan Soft Skills Matematik Siswa. Bandung: Refika Aditama.

Ishak, S., \& Irmayanti. 2018. Perbandingan Kemampuan Menyelesaikan Masalah Matematika pada Peserta Didik Laki-laki dan Perempuan Kelas VIII A SMP Negeri 4 Mamuju. Jurnal Pendidikan Pepatudzu: Media Pendidikan dan Sosial Kemasyarakatan, 4 (2), 172-186.

Kurniadi, G., \& Purwaningrum, J. P. 2018. Kesalahan Siswa pada Kategori Kemampuan Awal Matematis Rendah dalam Penyelesaian Tes Kemampuan Pemecahan Masalah Matematis. JPPM, 11 (2), 55-66.

Lestari, W. D. 2019. Kemampuan Pemecahan Masalah Siswa dalam Menyelesaikan Soal Cerita Aljabar Ditinjau dari Perbedaan 
Ita Rosita, Andrie Chaerul, dan Kiki Nia Sania Effendi

Anargya: Jurnal Pendidikan Matematika, Vol. 4 No.1, April 2021

https://dx.doi.org/10.24176/anargya.v4i1.6139

Gender. Skripsi pada Pendidikan

Matematika FKIP Universitas

Muhammadiyah Surakarta: Tidak

Diterbitkan.

Maswar. 2019. Profil Antisipasi Siswa SMP/MTs

dalam Memecahkan Masalah Aljabar

Ditinjau dari Kemampuan Matematika.

Indonesian Journal of Mathematics and Natural Science Education, 37-52.

Novitasari, \& Wilujeng, H. 2018. Analisis Kemampuan Pemecahan Masalah Matematika Siswa SMP Negeri 10 Tangerang. Prima : Jurnal Pendidikan Matematika, 2 (2), 137-147.

Nursyahidah, F., Rubowo, M. R., \& Saputro, B. A. 2018. Students Problem Solving Ability Based on Realistic Mathematics with Ethnomathematics. Journal of Research and Advances in Mathematics Education, 3 (1), 13-24.

Pardjijanti, E. 2019. Analisis Kemampuan Pemecahan Masalah Matematika Berorientasi OSN Ditinjau dari Gender pada Siswa Kelas VIII SMPN 26 Surakarta. Tesis pada Pascasarjana Magister Administrasi Pendidikan Universitas Muhammadiyah Surakarta.

Purwanto, W. R., Sukestiyarno, Y. L., \& Junaedi, I. 2019. Proses Berpikir Siswa dalam Memecahkan Masalah Matematika Ditinjau dari Persepektif Gender, Semarang: 11 Januari 2020, hal. 895- 900.
Salmina, M., \& Nisa, S. K. 2018. Kemampuan Penalaran Matematis Siswa Berdasarkan Gender pada Materi Geometri. Jurnal Numeracy, 41-48.

Santrock, J. W. 2015. Perkembangan Anak Jilid 2 Edisi Kesebelas. Jakarta: Erlangga.

Sari, R. A., \& Aripin, U. 2018. analisis kesalahan siswa dalam menyelesaikan soal certa bangun datar segiempat ditinjau dari kemampuan pemecahan masalah matematik untuk kelas VII. JPMI:Jurnal Pembelajaran Matematika Inovatif.

Susilowati, J. P. 2016. Profil Penalaran Siswa SMP dalam Pemecahan Masalah Matematika Ditinjau dari Perbedaan Gender . Jurnal Review Pembelajaran Matematika, 132-148.

Susilowati, J. P. 2016. Profil Penalaran Siswa SMP dalam Pemecahan Masalah Matematika Ditinjau dari Perbedaan Gender . Jurnal Review Pembelajaran Matematika, 132-148.

Tias, A. A., \& Wutsqa, D. U. 2015. Analisis Kesultan Siswa SMA dalam Pemecahan Masalah Matematika . Jurnal Riset Pendidikan Matematika, 2 (1), 28-39.

Ulya, H. 2015. Hubungan Gaya Kognitif dengan Kemampuan Pemecahan Masalah Matematika Siswa. Jurnal Konseling Gusjigang, 1 (2) , 410-442. 